\section{PACIFIC FINANCE SECTOR BRIEFS} ADB PACIFIC LIAISON AND COORDINATION OFFICE 
Table 1: Nominal Gross Domestic Product, 2011-2017

\begin{tabular}{|c|c|c|c|c|c|c|c|}
\hline & 2011 & 2012 & 2013 & 2014 & 2015 & 2016 & 2017 \\
\hline GDP (\$ million) & 418.0 & 473.0 & 450.0 & 442.0 & 441.0 & 400.0 & 420.0 \\
\hline M2 (\$ million) & 165.0 & 203.7 & 205.6 & 213.2 & 234.4 & 230.5 & 249.7 \\
\hline M2/GDP (\%) & 39.5 & 43.1 & 45.7 & 48.2 & 53.2 & 57.6 & 59.5 \\
\hline Private sector credit ( $\$$ million) & 135.0 & 144.2 & 138.5 & 138.5 & 150.7 & 157.0 & 172.2 \\
\hline Private sector credit/GDP (\%) & 32.3 & 30.5 & 30.8 & 31.3 & 34.2 & 39.2 & 41.1 \\
\hline
\end{tabular}

GDP = gross domestic product, $M 2$ = broad money.

Note: Figures were converted from pa'anga to United States dollars using the Asian Development Bank-recognized exchange rates for each year.

Sources: Asian Development Bank and International Monetary Fund.

\section{FINANCE SECTOR OVERVIEW}

\begin{abstract}
As with some Pacific island economies, Tonga remains moderately monetized, with private sector credit growing steadily since 2014. The ratio of Tonga's broad money (M2) to its GDP grew from 39.5\% to 59.5\% from 2011 to 2017, indicating a moderate monetization of the economy (Table 1 ). Meanwhile, the ratio of private sector credit to GDP declined in 2012 to $30.5 \%$ before rising steadily to $41.1 \%$ from 2013 to 2017 . The recovery of this ratio was "supported mainly by the implementation of the government-managed loan-subsidy scheme, lower lending rates, a boom in construction, and an increase in commercial loans" (IMF 2016).
\end{abstract}

\section{Tonga's finance sector is stable, but regulatory vigilance is} essential. The rebounding of the Tongan economy was made possible partly through accommodative monetary policy. This led to a rise in credit in the formal sector as well as better access to finance to promote inclusive growth. The IMF (2018) noted that growth in credit is consistent with financial deepening. However, Tonga's banks are monitored closely to avoid a buildup of systemic financial risks. Although the risks are minimal in relation to the Government of Tonga's subsidy scheme with certain financial institutions, lenient lending standards have the potential to become a problem. Moreover, the number of nonbank financial institutions is small and these institutions remain effectively unsupervised, which could become a concern in the future.

\section{FINANCE SECTOR STRUCTURE}

\section{Tonga's financial system lacks diversity, and is relatively} underdeveloped. There are four commercial banks licensed to operate in the country. ${ }^{1}$ Two of the four banks are branches of international banks (ANZ Banking Group and Bank of South Pacific), while the other two are locally incorporated (MBF Bank and the Tonga Development Bank). Tonga has four licensed and seven registered money transfer dealers.
The National Reserve Bank of Tonga (NRBT) is the country's central bank, and is responsible for the licensing, regulation, and supervision of financial institutions.

\section{The government is pushing for financial stability through improvements to the NRBT's supervision, regulation, and legal framework. The IMF (2018) recognized that efforts have been made to strengthen financial stability by amending the National Reserve Bank of Tonga Act and the Banking Act (formerly Financial Institutions Act), and raising banks' minimum reserve requirements to $10 \%$ of total deposits, but it also recommended that banks use flexible liquidity management tools as well as reserve requirements.}

\section{FINANCE SECTOR PERFORMANCE}

\section{Tonga's asset quality is improving and interest rate spreads} are narrowing. Available data indicate that Tonga's nonperforming loans ratio has been steadily declining since 2012. Meanwhile, interest rate spreads are narrowing, which may indicate increased banking sector competition and improved access to credit information (IMF 2016). Although the deposit rate fluctuated from 2011 to 2017, the lending rate gradually fell and this supported the recovery of credit provision from 2014 and 2017. Sustained flow of overseas remittances played a key role in the growth of the value of deposits, despite minimal improvement in deposit rates. The value of deposits grew at an average of 9.3\% a year from 2011 to 2017 .

\section{FINANCIAL INCLUSION}

Financial access in Tonga is high compared with some other Pacific island economies (Table 3). Compared to its peers in the Pacific, Tonga has the most commercial bank branches per 100,000 adults and the fourth most ATMs per 1,000 adults (IMF 2018). Although the value of commercial bank loans in the country is low, Tonga had the third most loan accounts with commercial banks per 1,000 adults in 2016.

1 There used to be five banks operating in Tonga. However, the National Reserve Bank of Tonga revoked the license of Pacific International Commercial Bank effective 26 July 2016 (http://www.reservebank.to/index.php/news-archives/366-revocation-of-pacific-international-commercial-bank\%E2\%80\%99slicense.html). When revoking the license, the National Reserve Bank of Tonga committed to pay out all of the Pacific International Commercial Bank's former deposits and creditors (http://www.reservebank.to/index.php/news-archives/374-pay-out-of-pacific-international-commercial-bank\%E2\%80\%99sdeposits-and-creditors.html). 
Table 2: Finance Sector Performance Indicators

\begin{tabular}{|c|c|c|c|c|c|c|c|}
\hline & 2011 & 2012 & 2013 & 2014 & 2015 & 2016 & 2017 \\
\hline NPL ratio (\%) & & 11.7 & 9.3 & 7.0 & 7.3 & 4.1 & 3.6 \\
\hline Deposits ( $\$$ million) & 50.0 & 66.6 & 77.8 & 78.1 & 90.5 & 89.8 & 81.1 \\
\hline Private sector credit ( $\$$ million) & 135.0 & 144.2 & 138.5 & 138.5 & 150.7 & 157.0 & 172.2 \\
\hline Deposit rate (\%) & 3.9 & 3.1 & 2.8 & 2.8 & 3.0 & 3.1 & 3.0 \\
\hline Lending rate (\%) & 11.4 & 9.9 & 9.4 & 8.6 & 8.2 & 7.9 & 7.9 \\
\hline
\end{tabular}

$\mathrm{NPL}=$ nonperforming loans.

Note: Figures were converted using Asian Development Bank's 2017 exchange rate.

Sources: International Monetary Fund and World Bank.

\section{Table 3: Financial Access Indicators}

\begin{tabular}{|c|c|c|c|c|c|c|c|}
\hline Access Indicators & 2011 & 2012 & 2013 & 2014 & 2015 & 2016 & 2017 \\
\hline Number of bank branches & 11 & 10 & 10 & 8 & 15 & 16 & 16 \\
\hline Number of ATMs & 18 & 18 & 18 & 18 & 19 & 22 & 25 \\
\hline Number of depositors with commercial banks & & & & & & 63,882 & 73,387 \\
\hline Number of deposit accounts with commercial banks & 38,203 & 48,653 & 52,424 & 60,735 & 69,560 & 53,722 & 74,998 \\
\hline Number of borrowers at commercial banks & & & & & & 10,872 & 10,648 \\
\hline Number of loan accounts with commercial banks & 6,673 & 4,492 & 8,664 & 7,006 & 10,973 & 11,238 & 10,707 \\
\hline
\end{tabular}

Note: Figures were converted using Asian Development Bank's 2017 exchange rate.

Source: International Monetary Fund.

Mobile money transactions are increasing over time, providing another opportunity to expand access to formal financial services.

The government is taking steps to broaden access to finance in Tonga. The IMF (2016) noted that the NRBT is currently implementing a project to finance small and medium-sized enterprises, as well as conducting a survey to determine the extent of credit demand across the country. Reforms to credit reporting and credit bureau coverage can help reduce the cost of conducting due diligence, which can expand access to finance. The IMF (2016) also observed that revisions to Tonga's Land Act would allow more people access to formal finance if land could be used as collateral for personal and business loans.

\section{REFERENCES}

Asian Development Bank. 2018. Key Indicators for Asia and the Pacific. Manila.

Asian Development Bank and Asian Development Bank Institute. 2015. Pacific Opportunities: Leveraging Asia's Growth. Manila.

International Monetary Fund. 2016. Tonga: Staff Report for the 2016 Article IV consultation. IMF Country Report. No. 16/178. Washington, DC.

_. 2018. Tonga: Staff Report for the 2017 Article IV consultation. IMF Country Report. No. 18/12. Washington, DC.

National Reserve Bank of Tonga website: http://www.reservebank.to/.

\section{About the Asian Development Bank}

ADB is committed to achieving a prosperous, inclusive, resilient, and sustainable Asia and the Pacific, while sustaining its efforts to eradicate extreme poverty. Established in 1966, it is owned by 68 members49 from the region. Its main instruments for helping its developing member countries are policy dialogue, loans, equity investments, guarantees, grants, and technical assistance.

This Finance Sector Brief was prepared by ADB's Pacific Department.

The views expressed in this publication are those of the authors and do not necessarily reflect the views and policies of ADB or its Board of Governors or the governments they represent.
Asian Development Bank

Pacific Liaison and Coordination Office

Level 20, 45 Clarence St, Sydney, 2000, Australia

+61282709429

www.adb.org/publications/pacific-finance-sector-tonga

Corrigenda to ADB publications may be found at http://www.adb.org/publications/corrigenda

In this publication, "\$” refers to US dollars.

All photos are from ADB. 